\title{
Allelopathy of a native grassland community as a potential mechanism of resistance against invasion by introduced plants
}

\author{
Lei Ning · Fei-Hai Yu • Mark van Kleunen
}

\begin{abstract}
Successful plant invasions depend, at least partly, on interactions between introduced plants and native plant communities. While allelopathic effects of introduced invaders on native resident species have received much attention, the reverse, i.e. allelopathic effects of native residents on introduced plants, have been largely neglected. Therefore, we tested whether allelopathy of native plant communities decreases their invasibility to introduced plant species. In addition, we tested among the introduced species whether the invasive ones are more tolerant to allelopathy of native plant communities than the non-invasive ones. To test these hypotheses, we grew nine pairs of related (congeneric or confamilial) invasive and non-invasive introduced plant species (i.e. 18 species) in the presence or absence of a native grassland community, which consisted of three common forbs and three common grasses, with or without activated carbon in the soil. Activated carbon reduced the survival percentage and growth of introduced plants in the absence of the native plant community. However, its net effect on the introduced plants was neutral or even
\end{abstract}

slightly positive in the presence of the native community. This might suggest that the native plant community imposed allelopathic effects on the introduced plants, and that these effects were neutralized or reduced by activated carbon. The invasive and non-invasive introduced plants, however, did not differ in their tolerance to such allelopathic effects of the native plant community. Thus, although allelopathy of native plant communities might increase their resistance against introduced plants, there was no evidence that tolerance to allelopathy of native plant communities contributes to the degree of invasiveness of introduced plants.

Keywords Activated carbon - Allelopathic chemicals · Competition - Introduced species . Invasibility · Invasiveness · Non-indigenous species

\section{Introduction}

Successful plant invasions depend, at least partly, on interactions between the introduced species and the native resident community (Inderjit and del Moral 1997; Verhoeven et al. 2009; Pearse et al. 2013; Qin et al. 2013; van Kleunen et al. 2015). In other words, invasion is determined by characteristics of the introduced species (driving their invasiveness) and by characteristics of the native recipient community (driving its invasibility; Richardson and Pysek 2006). 
Introduced species that successfully invade native communities are frequently regarded as strong competitors (Blossey and Nötzold 1995; Brown et al. 2002), and there is increasing evidence that several below-ground processes, such as root foraging and interactions with soil microbes, contribute to the outcome of competition (e.g. Klironomos 2002; Aschehoug et al. 2014; Keser et al. 2015). Another example of such a below-ground process is allelopathy, the direct or indirect chemical inhibitory effect of one species on another (Rice 1974; Callaway and Ridenour 2004). While allelopathic effects of introduced invasive species on native resident species have received much attention (e.g. Hierro and Callaway 2003; Orr et al. 2005; He et al. 2009; Jarchow and Cook 2009; Del Fabbro et al. 2014), the reverse the allelopathic effect of a native community on introduced species has been largely neglected (Cummings et al. 2012; Hou et al. 2012).

Plants produce many chemical compounds, some of which can, after their release in the soil, directly suppress the performance of neighboring plants (Inderjit and Callaway 2003; Inderjit and Duke 2003), or indirectly do so by inhibiting the growth of mycorrhizal fungi that are mutualists of the competitors (e.g. Stinson et al. 2006; Lankau 2013). Allelopathic substances are excreted directly into the soil, leached from plant tissues or released when dead plant material starts to decay (Hierro and Callaway 2003). The effects of these allelopathic substances might be strongest when species did not coevolve (Saul et al. 2013). Therefore, it has been suggested that many highly invasive introduced plant species can dominate plant communities because they produce allelopathic compounds that are novel to the native resident plants (Callaway and Ridenour 2004). Because of this novelty, and a lack of co-evolutionary history with the introduced invasive species (Verhoeven et al. 2009; Saul et al. 2013), the native species may be strongly affected by the allelopathic chemicals (Callaway and Vivanco 2007; Jarchow and Cook 2009; Gruntman et al. 2014). Indeed, there are many studies showing that the competitive ability of invasive introduced plants is partly mediated by allelopathy (Ens et al. 2009; Murrell et al. 2011; Bauer et al. 2012; Svensson et al. 2013; Del Fabbro et al. 2014), and thus might contribute to invasiveness.

If some introduced species can invade because they produce allelopathic chemicals that are novel to the native residents (Callaway and Ridenour 2004), the opposite might also be true. In other words, the native residents may produce allelopathic chemicals that are novel to an introduced species, and this might reduce invasibility of the community (see also the "Homeland Security Hypothesis" of Cummings et al. 2012). If allelopathy by a native community provides resistance against invasion by some introduced species, the fact that other introduced species have managed to invade these communities nevertheless suggests that such allelopathic effects are less strong on invasive introduced species than on non-invasive introduced species. The idea that invasive introduced species might be more tolerant to allelopathy than non-invasive introduced species are is not new. It was already proposed by Rabotnov (1982), and actually influenced the development of the novel-weapons hypothesis, in which the argument was turned around to pose that the invasive introduced species produce novel allelopathic compounds to which the resident community is not adapted (Hierro and Callaway 2003; Callaway and Ridenour 2004). Surprisingly, with the exception of a few studies on allelopathic effects of native tree species on forest invaders (Cummings et al. 2012; Hou et al. 2012), the original idea of Rabotnov (1982) has not been thoroughly tested yet.

In this study, we tested whether allelopathy of a native plant community may help to resist invasion by introduced plants. Therefore, we planted 18 introduced plant species into pots with and without a native plant community, and with and without activated carbon an allelopathy neutralizer in the soil. To test whether invasive introduced species are less strongly inhibited by allelopathy of the native community than non-invasive introduced species are, we chose the introduced species in such a way that we had nine pairs, each consisting of an invasive and a congeneric or confamilial noninvasive introduced species. Specifically, we tested the following questions: (1) Is there evidence for an allelopathic effect of the native community on survival percentage and biomass production of introduced plants? (2) If there is an allelopathic effect on introduced plants, is it stronger for noninvasive than for invasive ones? (3) Is the overall competitive effect of the native community on the introduced species stronger for the non-invasive species than for the invasive ones? 


\section{Materials and methods}

Study species and pre-cultivation

For this study, which took place in a greenhouse of the Botanical Garden of the University of Konstanz $\left(47^{\circ} 41^{\prime} 31.13^{\prime \prime} \mathrm{N}, 9^{\circ} 10^{\prime} 41.70^{\prime \prime} \mathrm{E}\right)$, Germany, we chose 18 herbaceous species that are introduced (i.e. nonnative) to Germany ("Appendix 1" section). The 18 introduced species were chosen in such a way that nine species are regarded as invasive (widespread) and the other nine as non-invasive (less widespread) in Germany. To avoid that our results would be biased by phylogenetic non-independence of species (Felsenstein 1985), we chose the introduced species in such a way that we had nine taxonomically related pairs of invasive and non-invasive introduced species (eight congeneric pairs and one confamilial pair). In other words, we avoided that all invasive introduced species belong to one taxonomic group and all non-invasive introduced species to another taxonomic group. All invasive introduced species occur in more than 900 of the 3000 grid cells $\left(1\right.$ grid cell $=10^{\prime}$ longitude $\times 6^{\prime}$ latitude $\sim 130 \mathrm{~km}^{2}$ ) of the German plantdistribution atlas (median $=1766$ ), and non-invasive introduced ones occur in fewer than 800 grid cells (median $=86$; data from FloraWeb 2014, http:// www.floraweb.de/; “Appendix 1" section). Within each of the nine taxonomic pairs, the invasive introduced species always occurred in at least four times as many grid cells as the non-invasive introduced species ("Appendix 1" section). All 18 introduced species are considered to be shade-intolerant, as they are mainly found in open habitats (i.e. not in forest habitats), such as grasslands, ruderal areas and agricultural fields (http://www.floraweb.de/). The seeds of the introduced species were provided by botanical gardens or bought from commercial seed suppliers in Europe ("Appendix 1" section).

For the native community, we chose six common species that are native to Germany and occur in grasslands and other open habitats. Three of them are grasses (Poa pratensis L., Dactylis glomerata L. and Lolium perenne L.), and the other three are forbs (Prunella vulgaris L., Plantago lanceolata L. and Daucus carota L.). Seeds of these six native species were bought from Rieger Hofmann GmbH (Blaufelden-Raboldshausen, Germany; http://www.riegerhofmann.de/).
On 6 and 10 December 2013, we sowed seeds of each of the six native species separately in trays (length $\times$ width $\times$ height $=59 \mathrm{~cm} \times 39 \mathrm{~cm} \times 7 \mathrm{~cm}) \quad$ filled with sand. Two weeks later, on 20 December 2013, we sowed seeds of each of the 18 introduced species separately in trays. To increase the germination rate, we exposed the seeds of Salvia aethiopis, Salvia verticillata, Lupinus polyphyllus and Bidens connata to 2 days of cold stratification, and we scarified the seeds of Lupinus albus and L. polyphyllus prior to sowing.

Experimental set-up

To test for effects of competition and allelopathy on introduced plants, we did a factorial experiment with two levels of competition (with or without a native plant community) crossed with two levels of activated-carbon addition (with or without). While many previous studies tested for allelopathy by applying plant extracts (e.g. Hou et al. 2012) or leaf litter (e.g. Cummings et al. 2012), we chose to work with live plants (and activated carbon), because we wanted to test whether the strength of competition is mediated by allelopathy (for other allelopathy studies using live plants, see Callaway and Ascheoug 2000; Lau et al. 2008).

We filled 2-L pots with a 1:1 mixture of sand and vermiculite. To provide the plants with sufficient nutrients during the experiment, we mixed $7 \mathrm{~g}$ Osmocote slow-release fertilizer (N:P:K:Mg = 16:9:12:2) into the substrate of each pot. For the treatment combinations with activated carbon, we mixed $40 \mathrm{ml}$ activated carbon (CASNO: 7440-44-0, EMD Millipore Corporation, Billerica MA, USA) into the substrate of each pot; and for the treatment combinations without activated carbon, we did not. The concentration of activated carbon that we used $(20 \mathrm{ml} / \mathrm{l})$ was also used in previous studies on allelopathy (Lau et al. 2008; Weißhuhn and Prati 2009). Activated carbon adsorbs and thereby neutralizes allelopathic substances (Mahall and Callaway 1992; Inderjit and Callaway 2003; Weißhuhn and Prati 2009). However, activated carbon can also have side effects on plant growth (Lau et al. 2008; Weißhuhn and Prati 2009; Kabouw et al. 2010; Wurst et al. 2010). Therefore, to reduce the likelihood that activatedcarbon addition would have side effects by adsorbing allelopathic compounds from organic materials that were already in the substrate and/or by increasing 
nutrient levels due to a boost in mineralization of organic materials (Lau et al. 2008), we used a nonorganic substrate (i.e. sand-vermiculite mixture). Furthermore, we added fertilizer into the substrate to avoid nutrient limitations, and thereby reduced potential side effects of activated-carbon addition on nutrient availability (Inderjit and Callaway 2003; Lau et al. 2008).

On 19 December 2013, we planted the native communities into half of the pots with activated carbon and into half of the pots without activated carbon. Each native community consisted of one plant of each of the six native grassland species, which were planted at equal distances in a circle around the center of each pot $($ diameter $=10 \mathrm{~cm})$. Three weeks later (on 10 January 2014), when the native communities were well established in the pots, we planted one introduced plant in the center of each pot with and without native community and with and without activated carbon. There were up to six replicates per introduced species and treatment combination. As three of the introduced species had low germination rates, we got slightly fewer than 24 plants (two species with 22 plants and one with 20 plants) for these species ("Appendix 1" section). As a consequence, the total number of pots in this experiment was 424 instead of 432 (i.e. 18 species $\times 2$ competition $\times 2$ activated carbon $\times 6$ replicates). Two plants of one of the introduced species, Solidago canadensis, died within 1 week after transplant, and these plants were immediately replaced.

While the experiment described above allowed us to test the effects of activated carbon on the introduced species when grown without native community, it did not allow us to test the effect of activated carbon on the native community. Therefore, to test for effects of activated carbon on the native community in the absence of introduced species, we also did a small parallel experiment on 44 pots with the native community without introduced species. Twenty-two of these pots had activated carbon in the substrate, and 22 pots did not have activated carbon.

The 424 pots of the main experiment and the 44 pots of the experiment with the native community only were randomly allocated to positions on three tables in a greenhouse. During the 10 weeks until harvest, the pots were re-randomized twice, and plants were watered regularly to prevent the soil from drying out. The light transmittance into the greenhouse was
$49 \%$, and additional lighting was provided to extend the daily light period to $14.5 \mathrm{~h}$. The minimum and maximum temperatures in the greenhouse were set to 18 and $21^{\circ} \mathrm{C}$.

\section{Measurements}

To be able to account for differences in initial sizes of the introduced plants in the analyses, we took initial size measurements at the beginning of the experiment, immediately after transplanting. We counted on each introduced plant the number of leaves, and measured the height of the plant and the length and width of the longest leaf. We calculated an estimate of total leaf area by multiplying the number of leaves and the length and width of the longest leaf.

On 2123 March 2014, we scored for each introduced plant whether it had survived or not, and harvested biomass of the ones that had survived. In all treatment combinations, we harvested aboveground biomass of the introduced plants. However, as it was impossible to separate the roots of the introduced plants from the roots of the native community, we harvested belowground biomass of the introduced plants only in the treatments without native community. We also harvested aboveground biomass of the native community, both in the main experiment and in the small experiment without introduced species. All biomass samples were dried at $70{ }^{\circ} \mathrm{C}$ for at least $72 \mathrm{~h}$, and then weighed.

\section{Statistical analyses}

We analyzed the data using the free software $\mathrm{R}$ (version 2.12.2; R Core Team 2011). To increase the statistical power for detecting differences between the group of invasive and the group of non-invasive introduced species, and to increase generality of the results, we had maximized the number of invasive and non-invasive introduced species over the number of replicate pots per species (van Kleunen et al. 2014). Therefore, we did not analyze each individual species separately, but analyzed all 18 introduced plant species jointly, while accounting for species identity.

Data on survival of the introduced plants were analyzed with a generalized linear mixed model with a binomial error distribution using the package "lme4" (Bates et al. 2014). As many more plants survived than 
died, we used the cloglog link instead of the default logit link (Egli and Schmid 2001). Aboveground biomass of the introduced plants was analyzed with a linear mixed model using the package "nlme" (Pinheiro et al. 2015). In these models, we included activated carbon (absent, present), competition (absent, present), invasiveness status in Germany (invasive, non-invasive) and their two- and three-way interactions as fixed terms. We accounted for differences in initial size of the introduced plants by including initial height and initial leaf area as covariates in the fixed model. Furthermore, we accounted for variation among species pairs and among species by including taxonomic pair and identity of the introduced species as random terms. To improve normality of the residuals, the data of aboveground biomass were $\log _{\mathrm{n}}$ transformed prior to analysis. To account for heterogeneity of variance, we used the varIdent variance structure implemented in the lme function to allow for different variances for each combination of species and activated-carbon treatment (Zuur et al. 2009).

In the (generalized) linear mixed models described above, we assessed the significance of the fixed terms with log-likelihood-ratio tests (Zuur et al. 2009). In these tests, a model with the term of interest is compared to a model without the term of interest, and the calculated log-likelihood ratios are approximately Chi squared $\left(\chi^{2}\right)$ distributed. We first compared models from which we had removed the three-way interaction (i.e. activated carbon $\times$ competition $\times$ invasiveness status) to the full model. If the fit of the two models differed significantly, then there was a significant effect of the three-way interaction. Then we removed each of the two-way interactions in turn from the model, and compared each of these models to a model with all two-way interactions but without the three-way interaction. In this way, we obtained the significance of each of three two-way interaction effects. After that, we removed the main effects of activated carbon, competition and invasiveness status in turn, and compared these three models to a model with all three main effects but without interactions to obtain the significance of each of the three main effects. Finally, we removed each of the two initialsize covariates in turn from the model, and compared these models to a model that had all two covariates but no other fixed terms to obtain the significance of the effect of each covariate.
To test whether activated carbon affected aboveground biomass of the native plant community in the absence of the introduced plants (i.e. in the small experiment with 44 pots), we used a $t$ test to compare biomass of the native plant community in the control pots with and without activated carbon. In the presence of the introduced plants (i.e. in the main experiment), aboveground biomass of the native plant community was analyzed with a linear mixed model and log-likelihood-ratio tests, with activated carbon (absent, present), invasiveness status (invasive, noninvasive) of introduced plants and their interaction as fixed terms. Taxonomic pair and identity of the introduced species were included as random terms.

\section{Results}

Survival of the introduced plants

Most introduced plants survived, and the survival percentage was on average not significantly affected by the presence of the native plant community (competition effect: $\chi^{2}=1.50, P=0.221$; Table 1 ). Averaged across all 18 introduced species and the two competition treatments, the addition of activated carbon significantly decreased survival percentage of the introduced plants from 86.3 to $78.6 \%$ (activated carbon effect: $\chi^{2}=6.16, \quad P=0.013$; Table 1). However, as indicated by a significant interaction between competition and activated-carbon addition $\left(\mathrm{C} \times\right.$ A effect: $\chi^{2}=4.26, P=0.039$; Table 1$)$, the magnitude of this negative effect depended on whether the native plant community was present or not. In the absence of the native plant community, survival percentage of the introduced plants decreased from 90.7 to $77.8 \%$ in response to activated-carbon addition, whereas in the presence of the native plant community, it decreased only slightly (from 81.9 to $79.4 \%$; Fig. 1a, b).

Averaged across all treatments, survival percentage did not differ between the invasive introduced species $(83.8 \pm 3.3 \%$, mean $\pm \mathrm{SE})$ and the non-invasive introduced species $(81.1 \pm 2.8 \%$; invasive status effect: $\chi^{2}=0.32, P=0.570$; Table 1; Fig. 1a, b). Responses of survival percentage to competition or to activated carbon also did not differ significantly between the invasive and non-invasive introduced 
Table 1 Results of generalized linear mixed models for survival and aboveground biomass of the nine invasive and nine non invasive introduced species grown in the presence or absence of the native plant community with or without the addition of activated carbon to the soil

\begin{tabular}{llllllr}
\hline Effect & $d f$ & \multicolumn{2}{l}{ Survival } & & \multicolumn{2}{l}{ Aboveground biomass } \\
& & $\chi^{2}$ & $P$ & & $\chi^{2}$ & \multicolumn{1}{c}{$P$} \\
\hline Fixed factor & 1 & 1.292 & 0.256 & & 12.993 & $<0.001$ \\
$\quad$ Initial height & 1 & 0.449 & 0.503 & & 2.236 & 0.135 \\
Initial leaf area & 1 & 0.322 & 0.570 & & 0.398 & 0.528 \\
Invasiveness status (S) & 1 & 1.495 & 0.221 & & 57.382 & $<0.001$ \\
Competition (C) & 1 & 6.157 & 0.013 & & 1.824 & 0.177 \\
Activated carbon (A) & 1 & 0.486 & 0.486 & & 0.991 & 0.320 \\
S $\times$ C & 1 & 1.131 & 0.288 & & 0.163 & 0.686 \\
S $\times$ A & 1 & 4.259 & 0.039 & & 14.384 & $<0.001$ \\
C $\times$ A & 1 & 0.541 & 0.462 & & 0.579 & 0.447 \\
S $\times$ C $\times$ A & $n$ & SD & & & SD & \\
Random factor & 9 & 1.642 & & & 1.387 & \\
Taxonomic pair & 18 & 0.736 & & & 1.206 & \\
Species identity & & & & & \\
\hline
\end{tabular}

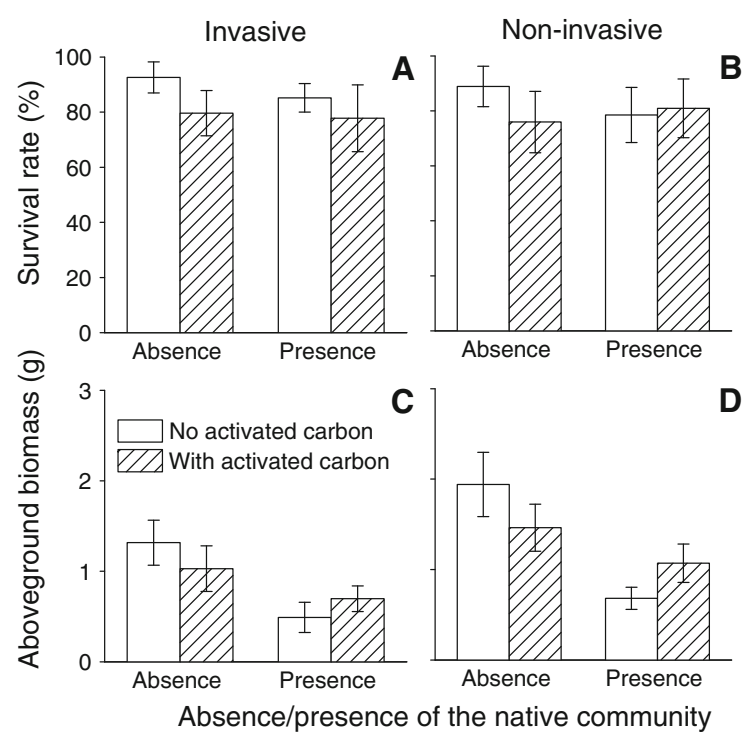

Fig. 1 Survival rate $(\mathbf{a}, \mathbf{b})$ and aboveground biomass $(\mathbf{c}, \mathbf{d})$ in the presence or absence of the native community with or without activated carbon averaged across the nine invasive $(\mathbf{a}, \mathbf{c})$ and the nine non invasive $(\mathbf{b}, \mathbf{d})$ species. Means \pm standard errors (based on averages per species) are given. See "Appendix 3" section for aboveground biomass of each individual species

species (no significant $\mathrm{S} \times \mathrm{A}, \mathrm{S} \times \mathrm{C}$ and $\mathrm{S} \times \mathrm{C} \times \mathrm{A}$ interactions in Table 1; Fig. 1a, b).

Biomass of the introduced plants

Among the surviving introduced plant species, the presence of the native plant community significantly reduced aboveground biomass by on average $48.9 \%$ $\left(\chi^{2}=57.38, P<0.001\right.$; Table 1; Fig. $\left.1 \mathrm{c}, \mathrm{d}\right)$. Averaged across all 18 introduced species and the two competition treatments, the addition of activated carbon had no significant effect on aboveground biomass $\left(\chi^{2}=1.82, P=0.177\right.$; Table 1 ; Fig. $\left.1 \mathrm{c}, \mathrm{d}\right)$. However, as was the case for survival percentage, the effect of activated-carbon addition on aboveground biomass depended on the presence of the native plant community, as indicated by a highly significant interaction between activated-carbon addition and competition $\left(\chi^{2}=14.38, P<0.001\right.$; Table 1$)$. In the absence of the native plant community, the addition of activated carbon reduced biomass of the introduced plants by on average $23.5 \%$ (Fig. 1c, d). However, in the presence of the native plant community, the addition of activated carbon increased biomass of the introduced species by on average $50.1 \%$ (Fig. 1c, d).

Averaged across all treatments, aboveground biomass did not differ between the invasive and the non-invasive introduced species $\left(\chi^{2}=0.40\right.$, $P=0.528$; Table 1; Fig. 1c, d). Responses of aboveground biomass to the presence of the native plant community or to activated carbon also did not differ significantly between the invasive and non-invasive introduced species (no significant $\mathrm{S} \times \mathrm{A}, \mathrm{S} \times \mathrm{C}$ and $\mathrm{S} \times \mathrm{C} \times \mathrm{A}$ interactions in Table 1; Fig. 1c, d).

For the subset of plants in the competition-free treatments (for which we could harvest belowground 
biomass in addition to aboveground biomass), there were no significant effects of activated carbon $\left(\chi^{2}=1.80, \quad P=0.180\right) \quad$ or invasiveness status $\left(\chi^{2}=0.52, P=0.472\right)$ on the ratio of aboveground to total biomass ("Appendix 2" section). This suggests that allocation of biomass to above- and belowground parts of the introduced plants is not affected by activated-carbon addition.

\section{Biomass of the native community}

All plants of the native community survived until the end of the experiment. In the subset of 44 pots with native species only (i.e. without introduced species), the addition of activated carbon did not significantly affect total biomass ( $t=1.10, d f=42, P=0.139)$ of the native communities. Nevertheless, due to a significant increase in belowground biomass by $32.8 \%(t=2.47, d f=42, P<0.001$; Fig. $2 \mathrm{a})$, the addition of activated carbon significantly decreased the relative allocation to aboveground parts $(t=2.58$, $d f=42, P=0.007$; “Appendix 4" section).

In the presence of the introduced plants in the main experiment, the addition of activated carbon significantly increased aboveground biomass of the native community (Table 2; Fig. 2b). The invasiveness status of the introduced plants had a significant effect on neither biomass of the native community nor the strength of the effect of activated carbon (Table 2; Fig. 2b).

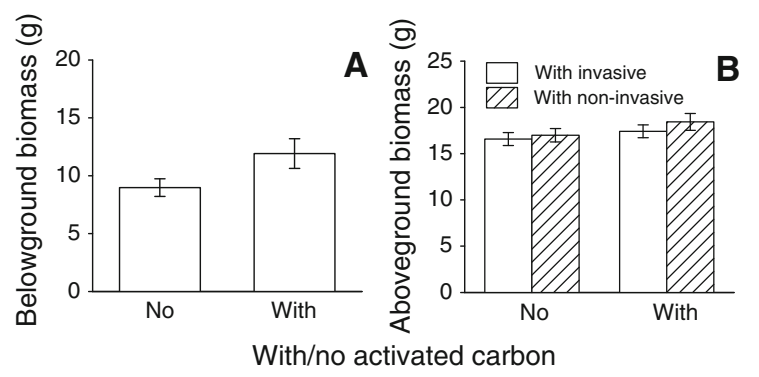

Fig. 2 Belowground biomass (a) of the native plant community in the absence of introduced plants with or without activated carbon, and aboveground biomass (b) of the native plant community in the presence of invasive or non invasive introduced plants with or without activated carbon. Means \pm standard errors are given
Table 2 Results of the generalized linear mixed model for aboveground biomass of the native plant community grown with invasive or non invasive introduced species with or without the addition of activated carbon to the soil

\begin{tabular}{llll}
\hline Effect & $d f$ & $\chi^{2}$ & $P$ \\
\hline Fixed factor & & & \\
Initial height & 1 & 0.328 & 0.567 \\
Initial leaf area & 1 & 0.003 & 0.957 \\
Invasiveness status (S) & 1 & 1.274 & 0.259 \\
Activated carbon (A) & 1 & 4.030 & 0.045 \\
S × A & 1 & 0.281 & 0.596 \\
Random factor & $n$ & SD & \\
Taxonomic pair & 9 & 0.562 & \\
Species identity & 18 & 0.655 & \\
\hline
\end{tabular}

\section{Discussion}

Allelopathy is of long-standing ecological interest (Wills 1985), and many studies have tested for allelopathic interactions between plants (e.g. Singh et al. 2003; Bais et al. 2006). Indeed, some of these studies have revealed evidence that some invasive introduced plant species produce allelopathic compounds that reduce native plant growth and thus may have facilitated invasion by the introduced species (e.g. Callaway and Ridenour 2004; Callaway and Vivanco 2007). Surprisingly, however, few studies have tested Rabotnov's hypothesis that allelopathy of native communities may resist invasion by introduced species (Rabotnov 1982). In this study, we showed that, despite negative effects of activated carbon on the survival percentage and growth of introduced plants in the absence of competition, this allelopathy-neutralizer had no or even positive net effects on these plants when grown with the native plant community (Fig. 1; Table 1), as well as on the native community (Fig. 2; Table 2). In other words, the potential negative effect of the native plant community on introduced plants, and vice versa, was alleviated by the addition of activated carbon. This significant interaction between activated-carbon addition and competition suggests that allelopathy of native plant communities may help to resist invasion by introduced species.

Many of the first ecological studies on the role of allelopathy in plant invasions used, like we did, activated carbon as an allelopathy neutralizer (e.g. 
Ridenour and Callaway 2001; Prati and Bossdorf 2004). Later studies called for caution in the interpretation of the results of these studies because of potential side effects of activated carbon on soil properties, microbes and plant growth (e.g. Abhilasha et al. 2008; Lau et al. 2008; Weißhuhn and Prati 2009; Kabouw et al. 2010; Wurst and Van Beersum 2009; Wurst et al. 2010; Kulmatiski 2011; Del Fabbro and Prati 2015; Nolan et al. 2015). For example, Kabouw et al. (2010) showed that despite the fact that activated carbon adsorbed glucosinolates very well-indicating the suitability of activated carbon for removing potentially allelopathic compounds it also changed the soil $\mathrm{pH}$ and had varying effects on germination of different plant species. Furthermore, Lau et al. (2008) suggested that activated carbon stimulated mineralization of nitrogen from organic materials in the potting mix they used, and that this resulted in faster growth of their plants. On the other hand, Wurst et al. (2010) found negative effects of activated carbon on plant growth, and suggested that this was due to interference of activated carbon with the chemical communication between the plants and their microbial mutualists, such as nitrogen fixing rhizobia in the case of legumes and mycorrhizal fungi. In our study, the slight positive net effect of activated carbon on aboveground biomass of the introduced plants in the presence of competition by the native plant community is unlikely due to positive direct effects of activated carbon, as it had negative effects in the absence of competition. Thus, although our results should certainly be interpreted cautiously because of potential side effect of activated carbon, it is likely that in the presence of competition, the allelopathyneutralizing effect of activated carbon compensated more than its direct negative effects on survival and growth of the introduced plants.

Given that invasive plants are obviously native in some parts of the world, it is certainly not surprising that native plants can also produce allelopathic chemicals (Reichard and White 2001; Young and Bush 2009). However, despite the fact that Rabotnov's hypothesis was posed more than three decades ago (Rabotnov 1982), there is little knowledge about the impact of allelopathic chemicals of native plants on introduced plants. Cummings et al. (2012) found that leaf litter from legume trees in Panama had an inhibitory effect on performance of the invasive C4 grass Saccharum spontaneum. Hou et al. (2012) tested the allelopathic response of the invasive Mikania micrantha to six dominant tree species in China, and found that leaf-litter extracts inhibited root growth of seedlings. Coupled with our findings, these results support the hypothesis of Rabotnov (1982) that allelopathy of native plant communities may be a mechanism of their resistance against invasion by some introduced plants.

Although our results indicate that the native plant community we used had an allelopathic effect on the introduced plants, invasive and non-invasive ones were affected to similar degrees. There was also no evidence that the presence of the native community resulted in a stronger growth reduction for noninvasive than for invasive introduced plants, or that the invasive and non-invasive introduced plants had different effects on the native community. Therefore, the results do not support our hypothesis that invasive introduced plant species have a higher ability of tolerating allelopathic substances and resource competition from native plant communities than noninvasive ones have. Although the chosen invasive species are common in Germany and occur in open, non-forested, habitats, many of them may be more abundant in disturbed habitats than in grasslands. Indeed, it has been suggested that European grassland communities are relatively resistant to invasions by introduced plants (Chytrý et al. 2009). In line with this, Kempel et al. (2013a) showed that, of the 45 native and 48 introduced species sown into grassland sites in Switzerland, it were mainly the native ones that were still present after 3 years. This suggests that grassland communities in Central Europe are less resistant to colonization by native species than to invasion by introduced species, possibly as a consequence of the long co-evolutionary history of native species. Future studies on the potential role of allelopathy in resistance of native communities to introduced species should thus also include native target plants as a control.

It is still too early for drawing general conclusions on the role of allelopathy of native communities in determining which introduced species become invasive. Nevertheless, the fact that invasive and noninvasive introduced species in our study were equally susceptible to competition and allelopathy by the native community indicates that other factors drive the differences in invasiveness of the introduced species used in our study. Some studies have revealed differences in traits between invasive and non- 
invasive introduced species, but few traits appear to consistently distinguish the invasive ones from the non-invasive ones (van Kleunen et al. 2015). For example, invasive species have frequently been found to be taller or produce more biomass than non-invasive introduced species (e.g. Schlaepfer et al. 2010; Kempel et al. 2013b). However, here we found no differences in survival percentage and aboveground biomass between the invasive and non-invasive introduced species. This suggests that the importance of many traits and other potential drivers for invasion success may be context dependent (Kueffer et al. 2013; van Kleunen et al. 2015), and that we need more studies that explicitly address this context dependency.

The native community that we used consisted of three forbs and three grasses. Although the six native species are very common in Germany, the assembled community represents only one specific type of native plant communities, and one that is not necessarily representative for other grassland communities. Therefore, to get a more general picture of the potential importance of allelopathy as a mechanism of resistance against invaders, future studies should use multiple communities of native plants (i.e. contexts), representative of different habitat types. Furthermore, because our native grassland community was in its initial stage of establishment, its potential allelopathic impact may have been weaker than that of an older plant community. For instance, allelopathic substances released through litter decomposition may be minimal in our assembled native grassland community, although they can contribute greatly to the allelopathic effects in natural communities (Inderjit et al. 2011). Therefore, we also need long-term experiments that allow native plant communities to fully establish and mature.

\section{Conclusions}

Our results indicate that allelopathy can play a role in resistance of native plant communities against invasion by introduced plants, despite that it could not help explain the invasiveness of the introduced plants in our study. We believe that it is worthwhile to pursue further research in this direction, and to use other complementary approaches such as exposure of introduced plants to extracts from native plant communities. Clearly, the time has come to finally test Rabotnov's hypothesis.

Acknowledgments We thank Otmar Ficht, Claudia Martin and Timo Scheu for assistance with the experiment, Wayne Dawson, Yanjie Liu, Mialy Razanajatovo, Ayub Oduor and Noëlie Maureland for helpful comments on earlier manuscript drafts, and the Fundamental Research Funds for the Central Universities (2015ZCQ BH 01), NSFC (31570413) and the China Scholarship Council for financial support.

\section{Appendix 1}

See Table 3.

Table 3 List of the 18 introduced species for which we tested whether they are affected by competitive and allelopathic effects of a native plant community in Germany

\begin{tabular}{|c|c|c|c|c|c|c|}
\hline Species & Family & $\begin{array}{l}\text { Native } \\
\text { continent }(\mathrm{s})^{*}\end{array}$ & $\begin{array}{l}\text { Status in } \\
\text { Germany }\end{array}$ & $\begin{array}{l}\text { No. grid } \\
\text { cells in } \\
\text { Germany }\end{array}$ & Seed supplier & $\begin{array}{l}\text { No. } \\
\text { plants }\end{array}$ \\
\hline $\begin{array}{l}\text { Amaranthus } \\
\text { graecizans }\end{array}$ & Amaranthaceae & $\begin{array}{l}\text { Africa, Asia, } \\
\text { Europe }\end{array}$ & $\begin{array}{l}\text { Non } \\
\text { invasive }\end{array}$ & 76 & $\begin{array}{l}\text { Botanical garden, University of } \\
\text { Regensburg, Germany }\end{array}$ & 24 \\
\hline $\begin{array}{l}\text { Amaranthus } \\
\text { retroflexus }\end{array}$ & Amaranthaceae & $\begin{array}{l}\text { North } \\
\text { America }\end{array}$ & Invasive & 2084 & $\begin{array}{l}\mathrm{B} \text { and } \mathrm{T} \text { world seeds, Aigues Vives, } \\
\text { France }\end{array}$ & $22^{\dagger}$ \\
\hline $\begin{array}{l}\text { Veronica } \\
\text { peregrine }\end{array}$ & Plantaginaceae & $\begin{array}{l}\text { North } \\
\text { America }\end{array}$ & $\begin{array}{l}\text { Non } \\
\text { invasive }\end{array}$ & 654 & Jadin Bontanique de Talance, France & 24 \\
\hline Veronica persica & Plantaginaceae & $\begin{array}{l}\text { Africa, Asia, } \\
\text { Europe }\end{array}$ & Invasive & 2863 & $\begin{array}{l}\mathrm{B} \text { and } \mathrm{T} \text { world seeds, Aigues Vives, } \\
\text { France }\end{array}$ & $22^{\dagger}$ \\
\hline S. aethiopis & Lamiaceae & Asia, Europe & $\begin{array}{l}\text { Non } \\
\text { invasive }\end{array}$ & 22 & Kräutergarten Storch, Erfurt, Germany & 24 \\
\hline S. verticillata & Lamiaceae & Asia, Europe & Invasive & 977 & Bioland, Germany & 24 \\
\hline
\end{tabular}


Table 3 continued

\begin{tabular}{|c|c|c|c|c|c|c|}
\hline Species & Family & $\begin{array}{l}\text { Native } \\
\text { continent(s)* }\end{array}$ & $\begin{array}{l}\text { Status in } \\
\text { Germany }\end{array}$ & $\begin{array}{l}\text { No. grid } \\
\text { cells in } \\
\text { Germany }\end{array}$ & Seed supplier & $\begin{array}{l}\text { No. } \\
\text { plants }\end{array}$ \\
\hline L. albus & Fabaceae & Asia, Europe & $\begin{array}{l}\text { Non } \\
\text { invasive }\end{array}$ & 86 & $\begin{array}{l}\text { Spicegarden Kräuter und Heilpflanzen, } \\
\text { Germany }\end{array}$ & 24 \\
\hline L. polyphyllus & Fabaceae & $\begin{array}{l}\text { North } \\
\text { America }\end{array}$ & Invasive & 2437 & Bioland, Germany & 24 \\
\hline Silene gallica & Caryophyllaceae & $\begin{array}{l}\text { Africa, Asia, } \\
\text { Europe }\end{array}$ & $\begin{array}{l}\text { Non } \\
\text { invasive }\end{array}$ & 155 & $\begin{array}{l}\text { Botanical garden, University of } \\
\text { Konstanz, Germany }\end{array}$ & 24 \\
\hline $\begin{array}{l}\text { Cerastium } \\
\text { tomentosum }\end{array}$ & Caryophyllaceae & Europe & Invasive & 1296 & $\begin{array}{l}\text { B and T world seeds, Aigues Vives, } \\
\text { France }\end{array}$ & 24 \\
\hline $\begin{array}{l}\text { Solidago } \\
\quad \text { graminifolia }\end{array}$ & Asteraceae & $\begin{array}{l}\text { North } \\
\text { America }\end{array}$ & $\begin{array}{l}\text { Non } \\
\text { invasive }\end{array}$ & 43 & $\begin{array}{l}\mathrm{B} \text { and } \mathrm{T} \text { world seeds, Aigues Vives, } \\
\text { France }\end{array}$ & 24 \\
\hline S. canadensis & Asteraceae & $\begin{array}{l}\text { North } \\
\text { America }\end{array}$ & Invasive & 2660 & $\begin{array}{l}\text { B and } \mathrm{T} \text { world seeds, Aigues Vives, } \\
\text { France }\end{array}$ & 24 \\
\hline $\begin{array}{l}\text { Sedum } \\
\text { ochroleucum }\end{array}$ & Crassulaceae & Asia, Europe & $\begin{array}{l}\text { Non } \\
\text { invasive }\end{array}$ & 7 & $\begin{array}{l}\text { B and } \mathrm{T} \text { world seeds, Aigues Vives, } \\
\text { France }\end{array}$ & 24 \\
\hline Sedum spurium & Crassulaceae & Asia & Invasive & 1625 & $\begin{array}{l}\text { Jelitto Staudensamen GmbH, } \\
\text { Schwarmstedt, Germany }\end{array}$ & 24 \\
\hline $\begin{array}{l}\text { Lepidium } \\
\text { heterophyllum }\end{array}$ & Brassicaceae & Europe & $\begin{array}{l}\text { Non } \\
\text { invasive }\end{array}$ & 98 & $\begin{array}{l}\text { Botanical garden, University of } \\
\text { Konstanz, Germany }\end{array}$ & 24 \\
\hline $\begin{array}{l}\text { Lepidium } \\
\text { virginicum }\end{array}$ & Brassicaceae & $\begin{array}{l}\text { North } \\
\text { America }\end{array}$ & Invasive & 849 & $\begin{array}{l}\text { Botanical garden, University of } \\
\text { Konstanz, Germany }\end{array}$ & 24 \\
\hline B. connata & Asteraceae & $\begin{array}{l}\text { North } \\
\text { America }\end{array}$ & $\begin{array}{l}\text { Non } \\
\text { invasive }\end{array}$ & 437 & $\begin{array}{l}\text { Botanical garden, University of } \\
\text { Konstanz, Germany }\end{array}$ & $20^{\dagger}$ \\
\hline Bidens frondosa & Asteraceae & $\begin{array}{l}\text { North } \\
\text { America }\end{array}$ & Invasive & 1766 & $\begin{array}{l}\text { Botanical garden, University of } \\
\text { Konstanz, Germany }\end{array}$ & 24 \\
\hline
\end{tabular}

The table lists for each alien species the native continent(s), invasiveness status in Germany (based on whether the species occurs in $<800$ (non invasive) or $>900$ (invasive) grid cells), number of $10^{\prime}$ longitude $\times 6^{\prime}$ latitude grid cells in which it occurs, the seed supplier, and the number of plants used in the experiment

* Based on information in http://www.ars grin.gov/cgi bin/npgs/html/tax search.pl

' Slightly fewer than 24 plants because of low germination rate

* Synonym of Euthamia graminifolia

\section{Appendix 2}

See Table 4.

Table 4 Results of a generalized linear mixed model for the ratio of shoot to total biomass of the nine invasive and nine non invasive introduced species grown in the absence of the native plant community with or without the addition of activated carbon to the soil

\begin{tabular}{llll}
\hline Effect & $d f$ & $\chi^{2}$ & $P$ \\
\hline Fixed factor & & & 0.472 \\
Invasiveness status (S) & 1 & 0.518 & 0.180 \\
Activated carbon (A) & 1 & 1.795 & 0.346 \\
S $\times$ A & 1 & 0.888 & SD \\
Random factor & $n$ & 0.022 & 0.023 \\
Taxonomic pair & 9 & & \\
Species identity & 18 & & \\
\hline
\end{tabular}




\section{Appendix 3}

See Fig. 3.

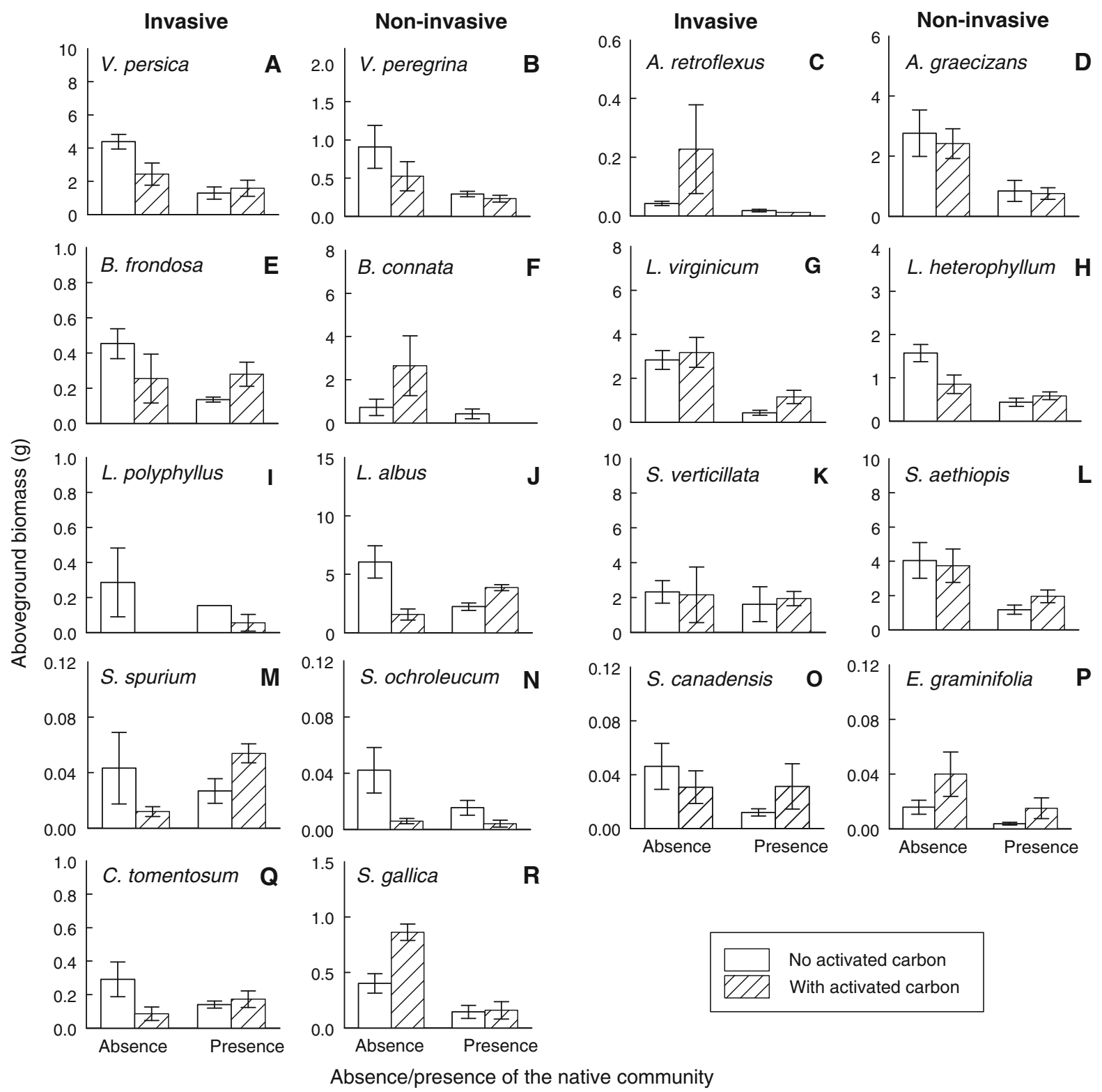

Fig. 3 Aboveground biomass (mean \pm standard error) of each of the nine invasive and the nine non invasive introduced or without activated carbon. See "Appendix 1" section for full species in the presence or absence of the native community with species names, and the scales of y axes differ among species 


\section{Appendix 4}

See Fig. 4.

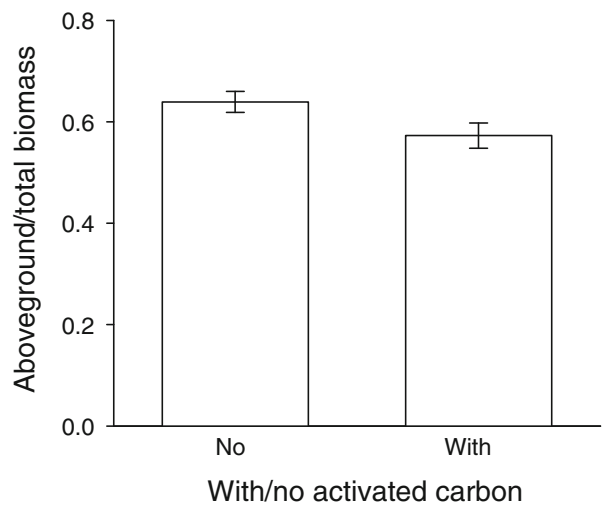

Fig. 4 Ratio of aboveground to total biomass (mean \pm stan dard error) of the native plant community in the absence of introduced plants with or without activated carbon

\section{References}

Abhilasha D, Quintana N, Vivanco J, Joshi J (2008) Do allelo pathic compounds in invasive Solidago canadensis s.l. restrain the native European flora? J Ecol 96:993 1001

Aschehoug E, Callaway R, Newcombe G, Tharayil N, Chen S (2014) Fungal endophyte increases the allelopathic effects of an invasive forb. Oecologia 175:285 291

Bais HP, Weir TL, Perry LG, Gilroy S, Vivanco JM (2006) The role of root exudates in rhizosphere interactions with plants and other organisms. Annu Rev Plant Biol 57:233 266

Bates D, Maechler M, Bolker B Walker S (2014) lme4: linear mixed effects models using Eigen and S4. R package version 1.1 7. http://CRAN.Rproject.org/package $=1 \mathrm{me} 4$

Bauer J, Shannon S, Stoops R, Reynolds H (2012) Context dependency of the allelopathic effects of Lonicera maackii on seed germination. Plant Ecol 213:1907 1916

Blossey B, Nötzold R (1995) Evolution of increased competitive ability in invasive nonindigenous plants: a hypothesis. J Ecol 83:887 889

Brown BJ, Mitchell RJ, Graham SA (2002) Competition for pollination between an invasive species (purple loosestrife) and a native congener. Ecology 83:2328 2336

Callaway RM, Ascheoug ET (2000) Invasive plants versus their new and old neighbours: a mechanism for exotic invasion. Science 290:521 523

Callaway RM, Ridenour WM (2004) Novel weapons: invasive success and the evolution of increased competitive ability. Front Ecol Environ 2:436 443

Callaway RM, Vivanco JM (2007) Invasion of plants into native communities using the underground information super highway. Allelopathy J 19:143 151
Chytrý MP, Pyšek J, Wild J, Pino L, Maskell C, Vilà M (2009) European map of alien plant invasions based on the quantitative assessment across habitats. Divers Distrib 15:98 107

Cummings J, Parker I, Gilbert G (2012) Allelopathy: a tool for weed management in forest restoration. Plant Ecol 213:1975 1989

Del Fabbro C, Prati D (2015) The relative importance of immediate allelopathy and allelopathic legacy in invasive plant species. Basic Appl Ecol 16:28 35

Del Fabbro C, Güsewell S, Prati D (2014) Allelopathic effects of three plant invaders on germination of native species: a field study. Biol Invasion 16:1035 1042

Egli P, Schmid B (2001) The analysis of complex leaf survival data. Basic Appl Ecol 2:223 231

Ens EJ, Bremner JB, French K, Korth J (2009) Identification of volatile compounds released by roots of an invasive plant, bitou bush (Chrysanthemoides monilifera spp. rotundata), and their inhibition of native seedling growth. Biol Inva sion 11:275 287

Felsenstein J (1985) Phylogenies and the comparative method. Am Nat 125:1 15

Gruntman M, Pehl A, Joshi S, Tielbörger K (2014) Competitive dominance of the invasive plant Impatiens glandulifera: using competitive effect and response with a vigorous neighbour. Biol Invasion 16:141 151

He WM, Feng Y, Ridenour W, Thelen G, Pollock J, Diaconu A, Callaway R (2009) Novel weapons and invasion: biogeo graphic differences in the competitive effects of Centaurea maculosa and its root exudate $( \pm)$ catechin. Oecologia 159:803 815

Hierro JL, Callaway RM (2003) Allelopathy and exotic plant invasion. Plant Soil 256:29 39

Hou Y, Peng S, Ni G, Chen L (2012) Inhibition of invasive species Mikania micrantha H.B.K. by native dominant trees in China. Allelopathy J 29:307 314

Inderjit, Callaway RM (2003) Experimental designs for the study of allelopathy. Plant Soil 256:1 11

Inderjit, del Moral R (1997) Is separating resource competition from allelopathy realistic? Bot Rev 63:221 230

Inderjit, Duke S (2003) Ecophysiological aspects of allelopathy. Planta 217:529 539

Inderjit, Wardle DA, Karban R, Callaway RM (2011) The ecosystem and evolutionary contexts of allelopathy. Trends Ecol Evol 26:655 662

Jarchow ME, Cook BJ (2009) Allelopathy as a mechanism for the invasion of Typha angustifolia. Plant Ecol 204:113 124

Kabouw P, Nab M, van Dam NM (2010) Activated carbon addition affects substrate $\mathrm{pH}$ and germination of six plant species. Soil Biol Biochem 42:1165 1167

Kempel A, Chrobock T, Fischer M, Rohr RP, van Kleunen M (2013a) Determinants of plant establishment success in a multispecies introduction experiment with native and alien species. Proc Natl Acad Sci 110:12727 12732

Kempel A, Nater P, Fischer M, van Kleunen M (2013b) Plant microbe herbivore interactions in invasive and non inva sive alien plant species. Funct Ecol 27:498 508

Keser LH, Visser EJW, Dawson W, Song Y B, Yu F H, Fischer M, Dong M, van Kleunen M (2015) Herbaceous plant species invading natural areas tend to have stronger 
adaptive root foraging than other naturalized species. Front Plant Sci 6:273

Klironomos JN (2002) Feedback with soil biota contributes to plant rarity and invasiveness in communities. Nature 417:67 70

Kueffer C, Pyšek P, Richardson DM (2013) Integrative invasion science: model organisms, multi site studies, unbiased meta analysis, and invasion syndromes. New Phytol 200:615 633

Kulmatiski A (2011) Changing soils to manage plant commu nities: activated carbon as a restoration tool in ex arable fields. Restor Ecol 19:102 110

Lankau RA (2013) Species invasion alters local adaptation to soil communities in a native plant. Ecology 94:32 41

Lau JA, Puliafico KP, Kopshever JA, Steltzer H, Jarvis EP, Schwarzländer M, Strauss SY, Hufbauer RA (2008) Inference of allelopathy is complicated by effects of acti vated carbon on plant growth. New Phytol 178:412 423

Mahall BE, Callaway RM (1992) Root communication mech anisms and intracommunity distributions of two Mojave Desert shrubs. Ecology 73:2145 2151

Murrell C, Gerber E, Krebs C, Parepa M, Schaffner U, Bossdorf $\mathrm{O}$ (2011) Invasive knotweed affects native plants through allelopathy. Am J Bot 98:38 43

Nolan N, Kulmatiski A, Beard KH, Norton J (2015) Activated carbon decreases invasive plant growth by meditating plant microbe interactions. AoB Plants 7:plu072. doi:10. 1093/aobpla/plu072

Orr SP, Rudgers JA, Clay K (2005) Invasive plants can inhibit native tree seedlings: testing potential allelopathic mech anisms. Plant Ecol 181:153 165

Pearse IS, Harris DJ, Karban R, Sih A (2013) Predicting novel herbivore plant interactions. Oikos 122:1554 1564

Pinheiro J, Bates D, DebRoy S, Sarkar D, R Core Team (2015) nlme: linear and nonlinear mixed effects models. R pack age version 3.1 119. http://CRAN.R project.org/package= nlme

Prati D, Bossdorf O (2004) Allelopathic inhibition of germina tion by Alliaria petiolata (Brassicaceae). Am J Bot 91:285 288

Qin RM, Zheng YL, Valiente Banuet A, Callaway RM, Barclay GF, Pereyra CS, Feng YL (2013) The evolution of increased competitive ability, innate competitive advan tages, and novel biochemical weapons act in concert for a tropical invader. New Phytol 197:979 988

R Development Core Team (2011) R: a language and environ ment for statistical computing. $\mathrm{R}$ foundation for statistical computing, Vienna. ISBN 390005107 0. http://www.R project.org/

Rabotnov TA (1982) Importance of the evolutionary approach to the study of allelopathy. Ékologia 3:5 8 (Translated from)

Reichard SH, White P (2001) Horticulture as a pathway of invasive plant introductions in the United States: most invasive plants have been introduced for horticultural use by nurseries, botanical gardens, and individuals. Bio science 51:103 113

Rice EL (1974) Allelopathy. Academic, New York

Richardson DM, Pysek P (2006) Plant invasions: merging the concepts of species invasiveness and community invasi bility. Prog Phys Geog 30:409 431

Ridenour WM, Callaway RM (2001) The relative importance of allelopathy in interference: the effects of an invasive weed on a native bunchgrass. Oecologia 126:444 450

Saul W, Jeschke J, Heger T (2013) The role of eco evolutionary experience in invasion success. NeoBiota 17:57 74

Schlaepfer DR, Glättli M, Fischer M, van Kleunen M (2010) A multi species experiment in their native range indicates pre adaptation of invasive alien plant species. New Phytol 185:1087 1099

Singh HP, Batish DR, Kohli RK (2003) Allelopathic interac tions and allelochemicals: new possibilities for sustainable weed management. Crit Rev Plant Sci 22:239 311

Stinson KA, Campbell SA, Powell JR, Wolfe BE, Callaway RM, Thelen GC, Hallett SG, Prati D, Klironomos JN (2006) Invasive plant suppresses the growth of native tree seedlings by disrupting belowground mutualisms. PLoS Biol 4:e140

Svensson JR, Nylund GM, Cervin G, Toth GB, Pavia H (2013) Novel chemical weapon of an exotic macroalga inhibits recruitment of native competitors in the invaded range. J Ecol 101:140 148

van Kleunen M, Dawson W, Bossdorf O, Fischer M (2014) The more the merrier: multi species experiments in ecology. Basic Appl Ecol 15:1 9

van Kleunen M, Dawson W, Maurel N (2015) Characteristics of successful alien plants. Mol Ecol 24:1954 1968

Verhoeven KJF, Biere A, Harvey JA, Der PuttenWH Van (2009) Plant invaders and their novel natural enemies: who is naive? Ecol Lett 12:107 117

Weißhuhn K, Prati D (2009) Activated carbon may have undesired side effects for testing allelopathy in invasive plants. Basic Appl Ecol 10:500 507

Wills RJ (1985) The historical bases of the condept of alleopathy. J Hist Biol 18:71 102

Wurst S, Van Beersum S (2009) The impact of soil organism composition and activated carbon on grass legume com petition. Plant Soil 314:1 9

Wurst S, Vender V, Rillig M (2010) Testing for allelopathic effects in plant competition: does activated carbon disrupt plant symbioses? Plant Ecol 211:19 26

Young GP, Bush JK (2009) Assessment of the allelopathic potential of Juniperus ashei on germination and growth of Bouteloua curtipendula. J Chem Ecol 35:74 80

Zuur A, Ieno EN, Walker N, Saveliev AA, Smith GM (2009) Mixed effects models and extensions in ecology with R. Springer, New York 